\title{
BIOMASS-BASED SOIL IN ECOLOGICAL AGRICULTURE: CHARACTERISTICS AND WHEAT GRAINS DEVELOPMENT TRENDS
}

\author{
Ramona Elena TĂTARU-FARMUȘ ${ }^{1}$, Carmen ZAHARIA ${ }^{2, *}$, \\ Daniela ȘUTEU ${ }^{3}$, Alexandra Cristina BLAGA ${ }^{3}$ \\ *E-mail: czah@ch.tuiasi.ro
}

Received: Dec. 14, 2021. Revised: Jan. 12, 2022. Accepted: Jan, 17, 2022 Published online: Feb. 2, 2022

\begin{abstract}
The biomass-based soils are used in the ecological agriculture, being already proposed in sustainable organic production systems with reduced costs for assuring the good cropping productivity, and also high quality of the crops. For the elimination of the synthetic inorganic fertilizers' utilization on soil, the use of certain types of residual biomass in mixture with the reference soil was proposed as they have a positive impact on the adsorption and absorption of nutrients and water for the nutrition of plants. The aim of this paper is to present four mixtures of reference soil and residual biomass, considered as biosoil used as support for development of wheat seeds. These biosoils were characterized in terms of real density, actual and potential $\mathrm{pH}$, content of total organic carbon, humus, exchangeable calcium, total and available nitrogen and phosphorus, and the trends of grain seeds germination and plants growth
\end{abstract}

were registered in association with the evolution of soil $\mathrm{pH}$ for a period greater than a month. The results encourage the use of these biosoils (mixtures of soil with residual biomass) as support for plants cropping.

Keywords: biosoil; ecological agriculture; grain seeds; mixture of soil and biomass; soil characteristics.

\section{INTRODUCTION}

The long-term cultivation of crops perrenials or annuals - causes intensive depletion of soil nutrients, and treatment with pesticides and fungicides against diseases and pests leads to the accumulation of heavy metals and other persistent organic pollutants (Vita et al., 2018; Compobenedetto et al., 2021). Perennials dry up the soil more

1 "Gheorghe Asachi" Technical University of lasi, "Cristofor Simionescu" Faculty of Chemical Engineering and Environmental Protection, Department of Chemical Engineering 73, Prof.Dr. docent D. Mangeron Blvd, lasi, Romania 2 "Gheorghe Asachi"Technical University of lasi, "Cristofor Simionescu" Faculty of Chemical Engineering and Environmental Protection, Department of Environmental Engineering and Management 73, Prof.Dr. docent D. Mangeron Blvd, lasi, Romania

3 "Gheorghe Asachi"Technical University of lasi, "Cristofor Simionescu" Faculty of Chemical Engineering and Environmental Protection, Department of Organical, Biochemical and Food Engineering 73, Prof.Dr. docent D. Mangeron Blvd, lasi, Romania 


\section{Ramona Elena TĂTARU-FARMUŞ ET AL.}

considerably than annual plants. The lack of microelements in the soil, such as $\mathrm{B}, \mathrm{Mn}, \mathrm{Zn}, \mathrm{Mo}, \mathrm{Fe}$, disrupts a number of metabolic processes (photosynthesis, activity of redox enzymes, carbohydrate metabolism etc.), which causes a decrease in plant productivity and product quality (Zahir et al., 2003; Tandzi and Mutengwa, 2020).

During the so-called "green revolution", farmers intervened on production systems, intensifying them, including in it large doses of nitrogen fertilizers. This trend has decreased in recent years, due to the increase in the cost of fertilizers and the expansion of water and soil pollution processes, as a result of non-compliance with cross-compliance measures (Compobenedetto et al., 2021). On the other hand, nitrogen oxide emissions from the expansion of fertilizer use are a concerning factor in global warming (Masclaux-Daubresse et al., 2010).

The methods of organic farming are based on techniques quite different from those of the green revolution, aiming to obtain healthier harvests and conservation of natural resources. A few significant distinctions between the organic farming and conventional agriculture can be underlined, such as no chemical pesticides is permitted, no synthetic fertilizers, or genetically modified organisms (GMOs) (Verhoog et al., 2003). Thus, organic, low-cost, sustainable and environmentally friendly production systems have been proposed which can ensure both a high crop quality and a good production/yield (Calvo et al., 2014; Banerjee et al., 2006). The use of biostimulators in plant nutrition was recommended by some researchers (Bashan and De-Bashan,
2010; Campobenedetto et al., 2021; Canbolat et al., 2006) to reduce, or replace the utilization of inorganic fertilizers, underlining the beneficial impact of biostimulators against the absorption or use of nutrients and water.

One of the main directions followed by contemporary agriculture to improve plant nutrition is the application of biotechnological processes with the following main trends:

$\checkmark$ the use of microorganism properties for the creation of biological products;

$\checkmark$ the increase of nutrients' accessibility to plants;

$\checkmark$ the optimization of resistance to diseases and pests.

The need to use biopreparations (e.g., certain residual biomass) is closely linked to the reduction of doses for the mineral and organic fertilizers traditionally used in agriculture. As a basis for most newly used biological products, they serve to the plant growth promoting bacteria (PGPB).

Among cereal crops, wheat ranks third in terms of cultivated area worldwide. Understanding the absorption, assimilation and use of fertilizers to improve their effective recovery in cereals has been a key objective in the grain research (Stępień and Wojtkowiak, 2016; Vita et al., 2018).

Wheat ensures very good results on fertile and permeable soils, in conditions of good humidity, in the absence of extreme temperatures. It is recommended to avoid sandy, salty, skeletal or heavily eroded soils as well as land frequently subjected to the location of water puddles (Cresser et al., 1993). At the level of 2018 year, in Romania, seed has produced from 150 varieties of wheat, 


\section{BIOMASS-BASED SOIL IN ECOLOGICAL AGRICULTURE}

many of these varieties insufficiently studied in different critical or extreme conditions of several years, fact that can make very difficult the selection of the corresponding varieties which allow to produce high and stable yields, but also very important at the same time.

Given these reported issues, the main objectives of this research work were: 1) to propose specific mixtures with soil and residual biomass (as biosoils) used as support for wheat seeds development, and 2) to compare the effect of certain biomass constituents residual (bacteria or yeast) in biofertilization system on plant development and yield.

\section{MATERIALS AND METHODS}

\section{Materials}

All experimental testings were performed by using the wheat variety Glosa, registered in 2005 by National Agricultural Research and Development Institute Fundulea (Romania), which has high ecological plasticity, good resistance to herringbone sprouting and good milling and bakery properties. It is recommending in all wheat cultivation/growing areas in Romania. The used reference soil is a cambic chernozem with clay texture and medium fertility, with neutral to alkaline reaction.

The reference soil samples for the experimental culture were taken from a private zone (Bucium, Straturi) of Iasi County area (Romania) at two depths: $0-10 \mathrm{~cm}$ and, respectively, $30-40 \mathrm{~cm}$ (as mentioned the soil sampling methodology for evaluation of the soil pollution level), which were mixed in a single sample. This reference sample was then air-dried, grounded and passed through a $2 \mathrm{~mm}$ mesh size stainless steel sieve before its analytical analysis as control / reference soil. The experimental protocol was based on the comparison between four types of biosoil, as described in Table 1 (Şuteu et al., 2021a,b).

Table 1 - Selected biosoils used for wheat cultivation

\begin{tabular}{|c|c|}
\hline Sample & Biosoil type (mixture of reference soil and biomass) \\
\hline $\begin{array}{l}\text { Control/ } \\
\text { reference }\end{array}$ & Reference soil* ${ }^{*}$ dried; was used only the fraction with particles size $<2 \mathrm{~mm}$ \\
\hline S1 & $\begin{array}{l}\text { Mixture of reference soil }{ }^{\star} / \text { residual biomass }=20: 1(\mathrm{w} / \mathrm{w}) \text {; the residual } \\
\text { biomass was of Lactobacillus } \mathrm{sp} \text {. bacteria immobilized in sodium alginate, } \\
\text { size range of } 0.5-1.5 \mathrm{~mm}\end{array}$ \\
\hline S2 & $\begin{array}{l}\text { Mixture of reference } \text { soil }^{\star} / \text { residual biomass }=40: 1(\mathrm{w} / \mathrm{w}) \text {; the residual } \\
\text { biomass was of Lactobacillus } \mathrm{sp} \text {. bacteria consortium immobilized in } \\
\text { sodium alginate (size range of } 0.5-1.5 \mathrm{~mm} \text { ) which retained anionic Orange } \\
16 \text { reactive dye by biosorption from controlled aqueous systems, C } \mathrm{C}_{\text {ads,max }}= \\
43.63 \mathrm{mg} / \mathrm{g}(\mathrm{d}=1.5 \mathrm{~mm})-221.77 \mathrm{mg} / \mathrm{g}(\mathrm{d}=0.5 \mathrm{~mm}) \text { (data under } \\
\text { evaluation) }\end{array}$ \\
\hline S3 & $\begin{array}{l}\text { Mixture of reference soil*/ residual biomass }=40: 1(\mathrm{w} / \mathrm{w}) \text {; the residual } \\
\text { biomass was of Lactobacillus } \mathrm{sp} \text {. bacteria consortium immobilized in } \\
\text { sodium alginate (size range of } 0.5-1.5 \mathrm{~mm} \text { ) which retained copper ions } \\
\text { from aqueous } \mathrm{CuSO}_{4} \text { solution by biosorption, biomass adsorption capacity } \\
\text { for } \mathrm{Cu}(\mathrm{II}) \text { ions of average } 375.05 \mathrm{mg} \mathrm{Cu}(\mathrm{II}) / \mathrm{g} \text { sorbent (data under } \\
\text { evaluation) }\end{array}$ \\
\hline S4 & $\begin{array}{l}\text { Mixture of reference soil }{ }^{*} \text { immobilized yeast }=30: 1(\mathrm{~g} / \mathrm{g}) \text {; the biomass } \\
\text { was represented by Saccharomyces cerevisiae, purchased from S.C. } \\
\text { ROMPAK S.R.L (Baker's yeast) immobilized on alginate beads (size } \\
\text { range of } 0.5-1.5 \mathrm{~mm} \text { ), containing } \mathrm{Zn}(\mathrm{II}) \text { in traces }\end{array}$ \\
\hline
\end{tabular}

Notes: * Main quality indicators of the reference soil were analyzed and summarized in Table 2; ** Şuteu et al., 2012a,b 


\section{Ramona Elena TĂTARU-FARMUŞ ET AL.}

The methodology used for the preparation and immobilization of the residual bacterial biomass, Lactobacillus sp. bacteria consortium in sodium alginate in form of macrospheres (diameters in range of 0.9 and $1.5 \mathrm{~mm}$ ) with maximum $5 \%$ of dried residual biomass, mixed with $1-1.5 \%$ sodium alginate solution at $70^{\circ} \mathrm{C}$, and prepared by dripping the mixture in $0.1 \mathrm{M} \mathrm{CaCl}_{2}$ solution) was reported in previous research works (Şuteu et al., 2021a,b).

Application of these prepared macrospheres as biosorbent in an advanced treatment step for certain aqueous systems (containing anionic reactive Orange dye or copper ions) has been reported in previous authors' works (Şuteu et al., 2021a,b) and the 'spent' biosorbent separated as byproduct was considered as residual biomass in this research work.

All chemical reagents used in the determination of a few of soil quality indicators were of analytical purity (p.a.) purchased from Merck Co, Fluka or other Romanian chemical companies).

\section{Methods}

\section{Experimental setup}

The effect of residual biomass based on Lactobacillus sp. bacteria consortium and yeast immobilized in sodium alginate, tested as organic fertilizers for proposed biosoils, was investigated on the yield of wheat under greenhouse or laboratory simulated conditions (2021, cropping season).

The germination and plant growth experiments were applied on studied biosoil samples (reffering to control / reference soil sample - without proposed organic fertilizer added) in pots with around $150 \mathrm{~g}$ till $300 \mathrm{~g}$, mainly consisting in series of experimental testings (conventional CRD experimental design, in homogeneous conditions), each series in three replications, prepared as described in Table 1: (i) control / reference series - using only the $M$ reference soil (without organic fertilizer), (ii) series 1 - using S1 biosoil with proposed organic fertilizer, (iii) series 2 - using S2 biosoil with proposed organic fertilizer containing organic dye, (iv) series 3 - using S3 biosoil with proposed organic fertilizer containing copper ions and (v) series 4 - using S4 biosoil with proposed organic fertilizer based on dry yeast. For the investigation of organic fertilization treatment against the soil characteristics, all pots were sown with 20 wheat seeds $\left(1^{\text {st }}\right.$ cultivation of soil samples) and then daily studied for at least 30 days at constant greenhouse/lab temperature to determine germination and evolution of plant growth.

As result, germination of a wheat seed begins with the absorption of soil water by the dried seeds at rest known as soaking. The number of germinated seeds was counting each day, being known the total number of seeds sown in the pots under the volume basis of growth media in terms of humidity ( $5 \mathrm{~mL}$ water / pot at each 2 days) and temperature (green-house/lab room temperature, around $19^{\circ}-23^{\circ} \mathrm{C}$ ) by visual observation of all cultivated biosoil samples.

All greenhouse/laboratory-scale set-up findings of wheat seeds germination and plants growth were performed in triplicate (supplementary data from ST1), in transparent pots/recipients (sizes of $20 \times 10 \times 8 \mathrm{~cm})$ loaded $(50-60 \%)$ with the prepared biosoil (S1-S4), or reference soil (M, control/reference soil sample).

The most relevant physical-chemical soil quality indicators, the biological growth parameters were analyzed, and the seed germination parameters were calculated.

\section{Seed germination parameters}

The principal germination parameter is considered to be the germination index. Thus, the final germination index (final germination percentage) (FGI) is calculated by dividing the germinated seeds in pot to the total number of sown seeds, multiplied by 100 (Hafez et al., 2021). 


\section{BIOMASS-BASED SOIL IN ECOLOGICAL AGRICULTURE}

It is also necessary the daily visual evaluation of each testing pot/recipient and the notation of biosoil/reference soil change rates/modifications, the maximum period of seeds germination and the evolution of plants height and growth rate trends (i.e., the increasing of cultivated plant height, in all three replications prepared for each series which use the M and S1-S4 biosoil samples).

\section{Analytical analysis methods used}

The four biosoils (S1-S4) and the reference soil without organic fertilizer treatment (M) were analyzed (each soil quality indicator was analyzed in five replications for data reproductibility validation) in our environmental chemistry laboratory, especially considering some principal quality indicators, i.e., density, actual and potential $\mathrm{pHs,} \mathrm{total} \mathrm{organic}$ carbon (TOC), total and available exchangeable calcium, total and available phosphorus and nitrogen content, using analytical analysis methods, internationally approved ${ }^{* * *}, 2008$; Cresser et al., 1993; LaMotte Co., 2008; Zaharia, 2014), which are shortly described further.

The values obtained after the laboratory analysis of each soil quality indicator (in five replications) for all experimental series are mediated and the experimental errors calculated by statistics, such as residual standard deviation or standard error of the mean value (Gluck, 1971; Liteanu, 1967), or as described in standard SR ISO 8466-1/1999 (e.g., standard error of the mean value $\left(\mathrm{s}_{\mathrm{y}}\right)$, or residual standard deviation $\mathrm{A}, \mathrm{A}=\left[\left(\mathrm{Yi}-\mathrm{Y}_{\mathrm{med}}\right) / \mathrm{Yi}\right]^{*} 100$ $(\%)$, where, $\mathrm{Yi}$ is the measured value of the soil quality indicator and $Y_{\text {med }}$ is the mean value of all replication values obtained for the corresponding soil quality indicator) which must be of no more than $\pm 10 \%$.

\section{Determination of soil density}

It was used the block mass density method (by weighting the amount of soil from a steel recipient of known volume), or the method with the soil pycnometer) (Cresser et al., 1993; Zaharia, 2014).

\section{Determination of actual and potential pH}

Both $\mathrm{pHs}$ are measured by direct reading of $\mathrm{pH}$ value with a waterproof HANNA pH-meter, after contacting of biosoil (S1-S4) or reference soil (M) sample $(10 \mathrm{~g})$ with distillated water (actual $\mathrm{pH}$, or $\mathrm{pH}$ of soil solution), or $\mathrm{KCl} 1 \%$ (potential $\mathrm{pH}$, or exchange acidity that can be produced by the soil colloidal fraction through chemical reaction in salty, or neutral buffer solutions) $\quad(50 \mathrm{~mL}$ solution used $)$ (Surpăţeanu and Zaharia, 2005).

\section{Determination of the total organic carbon (TOC)}

It was used the conventional method of oxidation using $\mathrm{K}_{2} \mathrm{Cr}_{2} \mathrm{O}_{7} 0.25 \mathrm{~N}$ in the presence of concentrated $\mathrm{H}_{2} \mathrm{SO}_{4}$ for more than 15-20 $\mathrm{min}$ on a heated sand bath, followed by sample titration with $0.2 \mathrm{~N}$ Mohr salt solution in the presence of Feroin indicator $(* * *, 2008$; Cresser et al., 1993; Zaharia, 2014).

\section{Determination of humus content}

It was used the extraction method, and TOC results, being applied an empirical correction (i.e., $1.72 * \mathrm{TOC}$ ) for the final humus content calculation (Cresser et al., 1993; Zaharia, 2014).

\section{Determination of exchangeable and available calcium ions for plants}

It was used the EDTA-based titration method, at $\mathrm{pH}=12-13$, in the presence of murexid indicator (Cresser et al., 1993; LaMotte Co., 2008; Zaharia, 2014).

\section{Determination of total and available nitrogen content}

The total nitrogen content is determined by using tests for Kjeldahl nitrogen and ammonia nitrogen; Kjeldahl test is based on mineralization of tested soil samples in concentrated $\mathrm{H}_{2} \mathrm{SO}_{4}$ and catalyst mixture $\left(\mathrm{K}_{2} \mathrm{SO}_{4}\right.$ and $\left.\mathrm{CuSO}_{4}\right)$ by heating onto a sand bath till greenish color, cooling and dilution with distillated water (adding $10 \mathrm{~N} \mathrm{NaOH}$ and 2-3 drops of phenolphthalein), followed by distillation and titration with $\mathrm{NaOH}$ or hydrochloric acid for ammonia content 


\section{Ramona Elena TĂTARU-FARMUŞ ET AL.}

measurement ( ${ }^{* * *}, 2008$; Gallego et al., 2017; LaMotte Co., 2008; Zaharia, 2014). For the available nitrogen content were used spectrometer-based tests for inorganic nitrogen measurement (nitrate, nitrite and ammonia) from aqueous soil extraction solution, standard internationally approved.

\section{Determination of the total and available phosphorus}

There are used phosphorus tests in alkaline soils with ammonia molibdate solution for available phosphorus (LaMotte Co., 2008); the same method was used after soil mineralization in concentrated acids for total phosphorus content ( ${ }^{* * *}, 2008$; Cresser et al., 1993; Zaharia, 2014).

The mean experimental data registered for all analyzed quality indicators of the cultivated control/ reference soil sample and cultivated biosoils (S1-S4 samples) will be further discussed in terms of the changes of the soil characteristics (variation of certain analyzed soil quality indicators), and also the wheat seeds germination progress, and plants growth evolution performed.

\section{RESULTS AND DISCUSSION}

The prepared biosoils were analyzed before and after being use for wheat plant development from seeds. The principal biosoils characteristics were briefly summarized in Table 2 . Accordingly, these soils had $\mathrm{pH}$ values (both active and potential $\mathrm{pH}$ ) near neutrality, being slightly alkaline, and their exchange acidity due to colloidal fraction is not high as the difference between both $\mathrm{pHs}$ is in the range of 0.2-0.7 units, thus is possible to have a lower micronutrient availability or some levels may be deficient. The average standard $\mathrm{pH}$ deviation in each testing series (five soil replications) related to their mean $\mathrm{pH}$ value was of $+0.052 \%$. These biosoils contained less than $0.05 \%$ of total phosphorus (available and unavailable) which is sufficient for a lot of crops cultivation, especially corn or wheat (usually a content of $0.05 \%$ of phosphorus is corresponding to $1120.81 \mathrm{~kg}$ of phosphorus per ha) and no retardation of grain growth, or vigor of both plant and animal is possible. The average standard deviation of experimental data related to the mean value for total phosphorus and available phosphorus (five replications) was of $+0.156 \%$ and, respectively, $+0.149 \%$. Moreover, the increasing of $\mathrm{pH}$ from moderate acidity towards neutrality, or slightly alkalinity favors the increasing of phosphorus availability steadily. This increase is exacerbated by the increased microbial activity as the soil $\mathrm{pH}$ increases, which results in increased mineralization of some of organic phosphorus. Above $\mathrm{pH}$ 7.5-7.8, the sparingly soluble calcium phosphate can precipitate in the presence of high calcium concentrations usually presented at moderate till high soil pH (Cresser et al., 1993). When the soil exceeds $\mathrm{pH} 8.5$, sodium dominates the cation exchange complex, and precipitation of calcium phosphate is less likely. The dominant form of phosphorus in the soil solution for most soils is $\mathrm{H}_{2} \mathrm{PO}_{4}^{-}$, although $\mathrm{HPO}_{4}{ }^{2-}$ becomes important in alkaline soils. The available phosphorus in the case of these biosoils (S1-S4) is of more than $40-45 \%$ from the total analyzed phosphorus content.

Nitrogen is involved in the majority of biochemical processes that compose and sustain animal and plant life being a constituent of the chlorophyll (green color) in plants and stimulating utilization of phosphorus, potassium and other essential elements, occurring in 
soil in both cationic (ammonium, $\mathrm{NH}_{4}{ }^{+}$) and anionic (nitrate- $\mathrm{NO}_{3}{ }^{-}$and nitrite$\mathrm{NO}_{2}{ }^{-}$) forms, but the greater part is present in organic forms. Due to the presence of residual biomass in biosoils (as organic fertilizer) the main source of nitrogen is through the decomposition of organic matter/ residual biomass (containing the essential organic compounds as nucleic acids, amino acids, enzymes and many vitamins). The analyzed values of total nitrogen (inorganic and organic $\mathrm{N}$ species) $(0.239-0.372 \%)$ are satisfactory for the wheat crop production. The average standard deviation for total nitrogen content (5 replications for each series, $\mathrm{S} 1-\mathrm{S} 4)$ was of $+1.082 \%$ (S1) till $1.654 \%$ (S2). Ammonia tends to be held on cation exchange sites and may be fixed in the soil matrix by vermiculite, and the nitrate is considered as a highly mobile anion which is not substantially adsorbed by the soil mineral components regardless of $\mathrm{pH}$ value. If the analyzed biosoil contains a large readily available nitrogen $(>0.5 \%$, e.g., from organic fertilizer and/or irrigation water containing high contents of nitrates, nitrites, etc.), the nitrate tends to be taken up by the soil microbial biomass, or by plants during the active growth period. Consequently, the nitrogen availability tends to depend upon the rate at which organic nitrogen is converted in inorganic nitrogen (mineralization), which is a temperature and $\mathrm{pH}$ dependent process (acidic conditions reduce the bacterial oxidation of ammonium to nitrate, thus low available nitrogen amount for plants growth, and also the mineralization rate declines above $\mathrm{pH} 8$ ). The available nitrogen $(0.103-0.167 \%)$ in the case of these biosoils (S1-S4) is of 50-60\% from the total nitrogen content, and the average standard deviation in the five replications is of $+1.243 \%$ (S1) till $+2.054 \%$ (S4).

The mean values of the total organic carbon content (five replications for each soil series) indicate a nondegraded soil, but with an acceptable $(0.799-2.230 \%)$ till moderate organic polluting level (5.224-5.580\%), and the mean standard deviation in all five replications is of $+1.246 \%$. The content of humus is relatively good for wheat crop production (1.378-9.621\%) with average standard deviation of replications in range of $(+) 0.754-1.246 \%$, and the available calcium content is not too high for large phosphates precipitation and allows its assimilation by plants. The average standard deviation in all five replications for available calcium content is varying in the range of $(+) 0.986 \%(\mathrm{M})-(+) 1.682 \%(\mathrm{~S} 4)$.

The values of all soil quality indicators decreased after the testing period of 30 days and for other crop cultivation (second cultivation), the soil treatment for nutrients enrichment is required thus organic fertilizer (i.e., supplementary residual immobilized biomass) may be added in biosoils and mineralization conditions kept active for nutrients supply of growing plants.

Values of certain quality indicators for tested biosoils (S1-S4) increased related to their values in the control/reference soil (pHs, TOC, density, humus, total/available $\mathrm{N}$ and $P$ content) as expressed in the change rate from Table 2 (last column), but for others (exchangeable calcium) beneficial decreases took place. 


\section{Ramona Elena TĂTARU-FARMUŞ ET AL.}

The Glosa wheat is considered an early variety of grain, resistant to drought, heat, wintering and rainfall, with medium resistance to the main foliar diseases, brown rust, yellow rust, flouring and septoriosis. It is the variety with the largest share of the wheat area cultivated in Romania (over 30\% in total area) in recent years. The wheat plants are grown from seeds introduced directly into the substrate (biosoil, depth of $1-2 \mathrm{~cm})$ from the germination pots/ recipients $(50-60 \%$ loaded with biosoil) and supervised for 30 days under controlled conditions of lab temperature and humidity, exposed to natural solar light. Plant growth (dependent of the number of sprouted grains, maximum height of plants etc.) was monitoring to evaluate the performance of residual biomass as organic fertilizer or additive in the soil composition. All plants were harvested on the $30^{\text {th }}$ day, measured and separated into roots and aerial part of the plant (stem with leaves).

Table 2 - Principal quality indicators of tested biosoils before wheat cultivation

\begin{tabular}{|c|c|c|c|c|c|c|}
\hline \multirow{2}{*}{$\begin{array}{l}\text { Quality } \\
\text { indicators }\end{array}$} & \multicolumn{5}{|c|}{ Measured value } & \multirow{2}{*}{$\begin{array}{c}\begin{array}{c}\text { Change rate in } \\
\text { biosoils (S1-S4) }\end{array} \\
\begin{array}{c}\text { vs. control soil } \\
\text { (M) }, \%\end{array}\end{array}$} \\
\hline & $\begin{array}{c}\mathrm{M}- \\
\text { control/ } \\
\text { reference }\end{array}$ & S1 & S2 & S3 & S4 & \\
\hline $\begin{array}{l}\text { Density, } \\
{\mathrm{g} / \mathrm{cm}^{3}}^{3}\end{array}$ & 1.047 & 1.025 & 1.044 & 1.031 & 1.064 & $\begin{array}{c}(-1.55)(\mathrm{S} 3)- \\
(+2.15)(\mathrm{S} 4)\end{array}$ \\
\hline $\begin{array}{l}\text { Actual / active } \\
\mathrm{pH}\end{array}$ & 7.6 & 7.8 & 7.9 & 7.9 & 7.7 & $\begin{array}{c}(+1.29)(\mathrm{S} 4)- \\
(+3.80)(\mathrm{S} 4)\end{array}$ \\
\hline $\begin{array}{l}\text { Potential/ } \\
\text { exchangeable } \\
\text { pH }\end{array}$ & 7.4 & 7.5 & 7.3 & 7.2 & 7.4 & $\begin{array}{c}(-2.78)(\mathrm{S} 3)- \\
(+1.33)(\mathrm{S} 1)\end{array}$ \\
\hline TOC, \% & 0.799 & 5.224 & 5.580 & 2.230 & 2.134 & $\begin{array}{c}+64.56)(\mathrm{S} 4)- \\
(+85.68)(\mathrm{S} 2)\end{array}$ \\
\hline Humus, \% & 1.378 & 9.006 & 9.621 & 3.845 & 3.680 & $\begin{array}{c}(+62.55)(\mathrm{S} 4)- \\
(+85.68)(\mathrm{S} 2)\end{array}$ \\
\hline $\begin{array}{l}\text { Total } \mathrm{N} \\
\text { (TN), \% }\end{array}$ & 0.261 & 0.342 & 0.372 & 0.239 & 0.268 & $\begin{array}{c}(-9.21)(\mathrm{S} 3)- \\
(+29.84)(\mathrm{S} 2)\end{array}$ \\
\hline $\begin{array}{l}\text { Available N } \\
\text { from TN, \% }\end{array}$ & 0.104 & 0.137 & 0.167 & 0.103 & 0.110 & $\begin{array}{l}(-0.97)(\mathrm{S} 3)- \\
(+37.72)(\mathrm{S} 2)\end{array}$ \\
\hline $\begin{array}{l}\text { Total P (TP), } \\
\mathrm{mg} / \mathrm{kg} \text { soil }\end{array}$ & 0.045 & 0.048 & 0.050 & 0.048 & 0.048 & $\begin{array}{c}(+8.25)(\mathrm{S} 1, \mathrm{~S} 3, \mathrm{~S} 4)- \\
(10)(\mathrm{S} 2)\end{array}$ \\
\hline $\begin{array}{l}\text { Available P } \\
\text { from TP, mg/ } \\
\text { kg of dry soil }\end{array}$ & 0.023 & 0.026 & 0.029 & 0.026 & 0.026 & $\begin{array}{c}(11.5)(\mathrm{S} 1, \mathrm{~S} 3-4)- \\
(20.7)(\mathrm{S} 2)\end{array}$ \\
\hline $\begin{array}{l}\text { Exchangeable } \\
\text { calcium (Ca), } \\
\mathrm{mg} / \mathrm{kg} \text { of dry } \\
\text { soil }\end{array}$ & 5120.9 & 4417.9 & 4512.7 & 3440.6 & 2941.9 & $\begin{array}{c}(-74.07)(\mathrm{S} 4)-(- \\
13.48)(\mathrm{S} 2)\end{array}$ \\
\hline
\end{tabular}

"High change rate of the soil quality characteristics due to the biomass-based organic fertilizer treatment can be considered when the value of change rate is higher than $50 \%$ (i.e., TOC, humus content, exchangeable calcium content), moderate when is in range of $20-50 \%$ (e.g., TN and available $\mathrm{N}$ content) and low or almost unchanged when is in range of $10-20 \%$ (available P content), or $0-10 \%$ (density, pHs, TP). 


\section{BIOMASS-BASED SOIL IN ECOLOGICAL AGRICULTURE}

During 30 days, measurements of soil $\mathrm{pH}$ were done (Fig. 1), as well as measurements of the height of the plants as shown in Figs. 2, 3 and 4. PH of biosoil samples had a lower micronutrient availability and some levels may be deficient. The presence of anionic reactive dye in $\mathrm{S} 2$ biosoil composition increases the sample $\mathrm{pH}$ related to the control/reference soil (Fig. 1). The same trend is maintained in the case of S3 biosoil sample with residual biomass and $\mathrm{Cu}$-microelement (Fig. 1), with the finding that, with one exception, the $\mathrm{pH}$ values are below the $\mathrm{pH}$ of S2 sample. It is possible that the $\mathrm{Cu}$ microelement is only partially in soluble form in the substrate precisely because of the slightly alkaline $\mathrm{pH}$ (present as complexes of hydro/hydroxi-coordinated metal compounds).

Due to the stabilization/ mineralization process of organic matter, implicitly of biomass-based organic fertilizer added to the reference soil, the soil acidity was slightly increased and the available copper ion species for microorganisms and plant growth released from soil complex matrix to be consumed in the metabolic process of living microorganisms and for plant growth. During the experimental testing period, the variation of biosoil $\mathrm{pH}$ was not extreme, remaining in the relative acceptable range (neutral $\mathrm{pH}$ - slightly alkaline level) thus permitting the activity of soil microorganisms and development of the aerial part of plants. The clear differences of $\mathrm{pHs}$ during the cultivation period related to their initial values from Table 1 are indicators of the changes produced during the stabilization/ mineralization process in soil structure when available inorganic species (e.g.,
$\mathrm{N}-\mathrm{NO}_{2}^{-}, \mathrm{P}-\mathrm{H}_{2} \mathrm{PO}_{4}^{-}, \mathrm{K}^{+}$and $\mathrm{Cu}^{2+}$ ions) were generated and consumed by growing plants and living microorganisms, but precipitation/co-precipitation of calcium phosphate is possible to be performed ( $\mathrm{pH}>8.0-8.50)$, too.

A new cultivation of biosoil is possible (second cultivation), but is required the biosoil enrichment with nutrients from organic fertilizers or other supplementary sources.

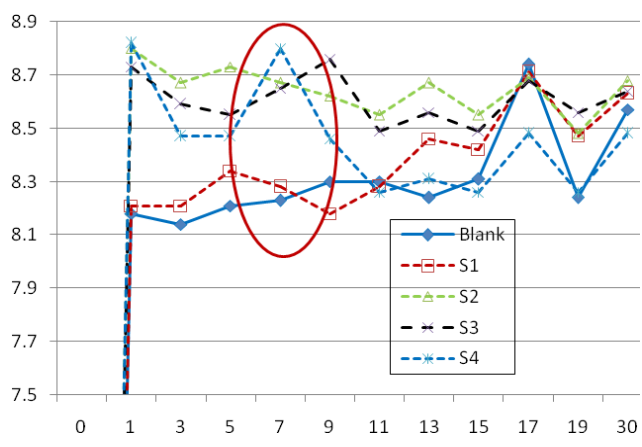

Figure 1- Variation curve of biosoil pH $(y)$ in the cultivation period ( $x, 30$ days)

The height of the plants was measured at each 48 hours-interval and the registered data are presented in Table 3.

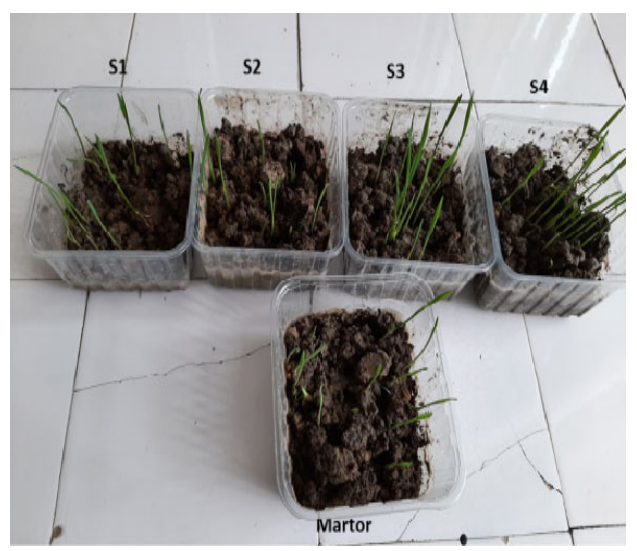

Figure 2 - Visual analysis of wheat seeds germination after 5 days for all prepared biosoils (references M, S1-S4) 


\section{Ramona Elena TĂTARU-FARMUŞ ET AL.}

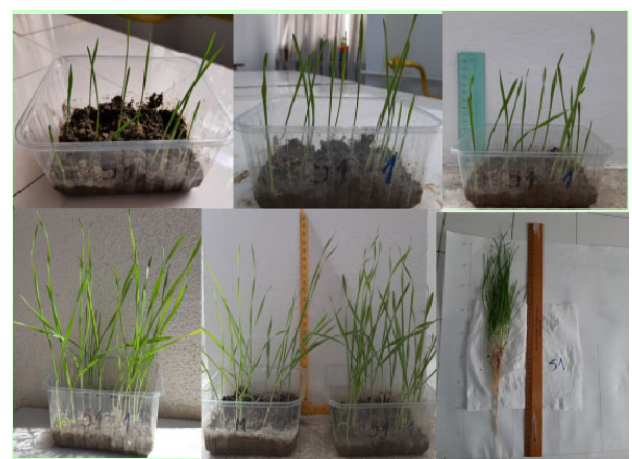

Figure 3 - Plant development in S1 biosoil sample (soil/biomass $40: 1$ )

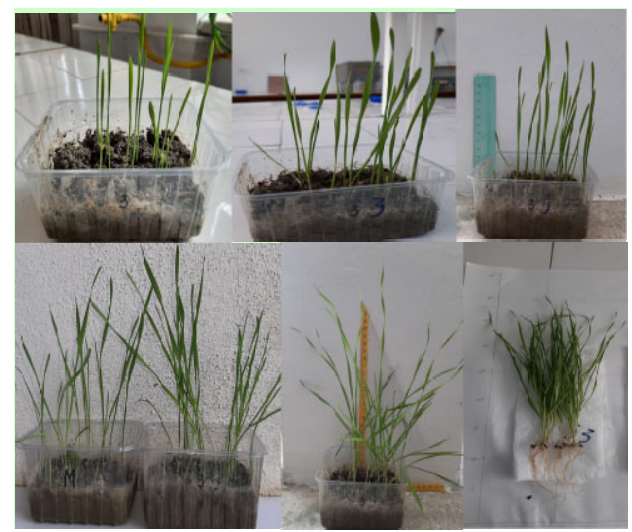

Figure 4- Plant development in S3 biosoil sample (soil/biomass/Cu species 40:1)
The minimum value of the germination index was determined in the control/reference soil $(60 \%)$, the soil sample where the nutrients' content is minimal (Table 4). The maximum value of the germination index (sprouting yield) was recorded in the samples with the addition of residual biomass (S1), biomass with adsorbed $\mathrm{Cu}$-species (S3), and, respectively, with yeast (S4). The minimal value of the final germination index was found in the S2 biosoil sample containing mixture of soil and residual biomass with adsorbed anionic reactive dye $(\mathrm{RO})$ in the series of treated reference soil with organic fertilizer (residual biomass). The presence of reactive dye in this biosoil sample inhibits slightly the sprouting of the grains both in terms of the number of sprouted grains and also duration of the sprouting time, which is also reported in the scientific literature (Hafez et al., 2021; Rehman et al., 2018; Lellis et al., 2019), but plant development was better related to the control/ reference soil sample with no organic fertilizer, i.e., residual biomass / yeast.

Table 3 - Mean value of the aerial wheat plant height in the testing samples

\begin{tabular}{cccccc}
\hline \multirow{2}{*}{ Time (days) } & \multicolumn{5}{c}{ Height of aerial plant- $\mathbf{H}_{\text {plant }}(\mathbf{c m})$} \\
\cline { 2 - 6 } & Control/blank & $\mathbf{S 1}$ & $\mathbf{S 2}$ & $\mathbf{S 3}$ & $\mathbf{S 4}$ \\
\hline 5 & 5.5 & 5.3 & 5.7 & 5.8 & 5.5 \\
\hline 7 & 7.2 & 7.9 & 7.2 & 7.7 & 7.6 \\
\hline 9 & 12.3 & 13.6 & 13.2 & 14.2 & 14.2 \\
\hline 11 & 14.7 & 15.3 & 15.0 & 15.4 & 15.4 \\
\hline 13 & 15.1 & 15.6 & 15.4 & 15.9 & 16.0 \\
\hline 15 & 15.5 & 16.5 & 17.0 & 18.7 & 19.5 \\
\hline 17 & 16.5 & 17.1 & 19.5 & 20.2 & 20.2 \\
\hline 19 & 20.1 & 21.3 & 20.8 & 23.3 & 22.3 \\
\hline 21 & 21.3 & 22.7 & 22.4 & 23.7 & 23.8 \\
\hline 30 & 22.6 & 24.3 & 24.6 & 24.6 & 25.2 \\
\hline Max H & 30.5 & 30.5 & 33.5 & 30.2 & 33.2 \\
\hline
\end{tabular}

The differences recorded in-time of the mean aerial wheat plant height (in all triplicate series) are important for each series treated with organic fertilizer 


\section{BIOMASS-BASED SOIL IN ECOLOGICAL AGRICULTURE}

(residual biomass) referring to the control/reference non-treated soil (as shown in the supplementary data from ST1), varying in the range of $1.7-2.6 \mathrm{~cm}$, but the differences of the mean plant height in only biosoils (S1-S4) is not too high (in range of 0.6-0.9), fact which underlined the key role of organic fertilizer in plant growth improvement.

In the testing biosoil samples with (40:1) mixture of reference soil and residual biomass with adsorbed $\mathrm{Cu}$ (II) species (S3), respectively, soil and yeast (S4), the mean height of aerial wheat plant is higher than in the control/reference sample (M) (as shown by statistical data processing which are summarized in Table 5 and supplementary data from table ST1 with measured height of each wheat plant after 30 days of growth), respectively the mixture (40:1) of soil and residual biomass with adsorbed RO dye (S2). It is assumed that in the biosoil samples in which residual biomass with micro-nutrients $(\mathrm{Cu})$ was applied (S3) and also yeast (S4), much intense growth and development of aerial plants is performed due to the higher accessibility of nutrients (Figs. 2-4).

Table 4 - Germination index values of prepared biosoils vs. reference soil (blank M)

\begin{tabular}{lcccccc}
\hline Sample & & Blank & S1 & S2 & S3 & S4 \\
\hline Seeds No. & & 20 & 20 & 20 & 20 & 20 \\
\hline \multirow{3}{*}{ Sprouted grains } & $2^{\text {nd }}$ day & 9 & 17 & 11 & 16 & 16 \\
\cline { 2 - 7 } & $3^{\text {rd }}$ day & 12 & 20 & 13 & 20 & 20 \\
\cline { 2 - 7 } & $4^{\text {th }}$ day & 12 & 20 & 16 & 20 & 20 \\
\hline Germination index, $\%$ & 60 & 100 & 80 & 100 & 100 \\
\hline
\end{tabular}

Table 5 - Statistical parameters for the mean heights of aerial wheat plant part in biosoil samples and reference soil (details in supplementary data ST1)

\begin{tabular}{lccccc}
\hline \multirow{2}{*}{ Statistical parameter } & \multicolumn{5}{c}{ Soil / biosoil type } \\
\cline { 2 - 6 } & Control/ blank(M) & S1 & S2 & S3 & S4 \\
\hline $\mathbf{n}$, no. of wheat plant & 12 & 20 & 16 & 20 & 20 \\
\hline $\mathbf{Y}_{\text {med, mean height, }[\mathrm{cm}]}$ & 22.6 & 24.3 & 24.6 & 24.6 & 25.2 \\
\hline $\mathbf{s}^{2}$, average deviation & 14.29 & 2.38 & 10.61 & 1.87 & 3.72 \\
\hline $\mathbf{s}$, square average deviation & 3.78 & 1.54 & 3.26 & 1.37 & 1.93 \\
\hline $\mathbf{s}_{\text {ymed }}$ standard error of the mean & 1.09 & 0.35 & 0.81 & 0.31 & 0.43 \\
\hline
\end{tabular}

No chlorosis and necrosis was observed in the aerial wheat plants developed on biosoils based on residual biomass and yeast, which is noticeable in the case of the control/reference soil (M) (Fig. 5).

In the $30^{\text {th }}$ day of testing, the maximum value of the aerial wheat plant height was not register on the samples S3 and S4, which constantly had an increasing trend, superior to the other samples, but only on the sample S2 containing adsorbed textile dye (Fig. 6).

This can be explained by the fact that the branching of the plant is more pronounced in the S3 and S4 biosoil samples, rather than the growth in aerial plant height (Table 3). 


\section{Ramona Elena TĂTARU-FARMUŞ ET AL.}

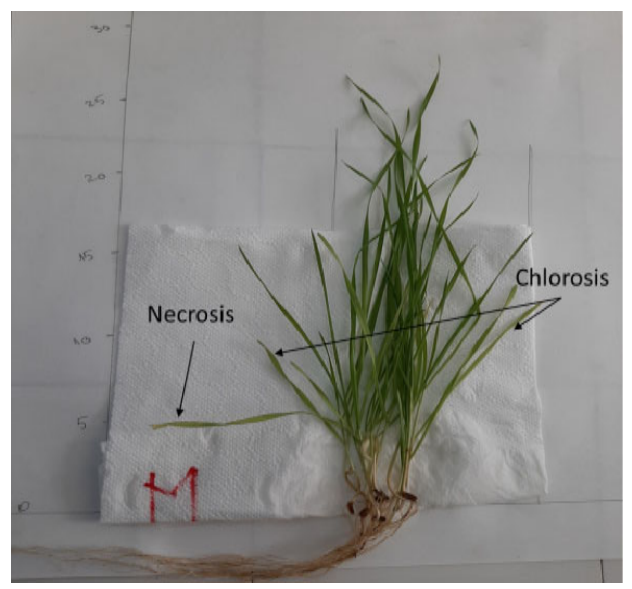

Figure 5 - Necrosis development in the control/references soil sample (M)

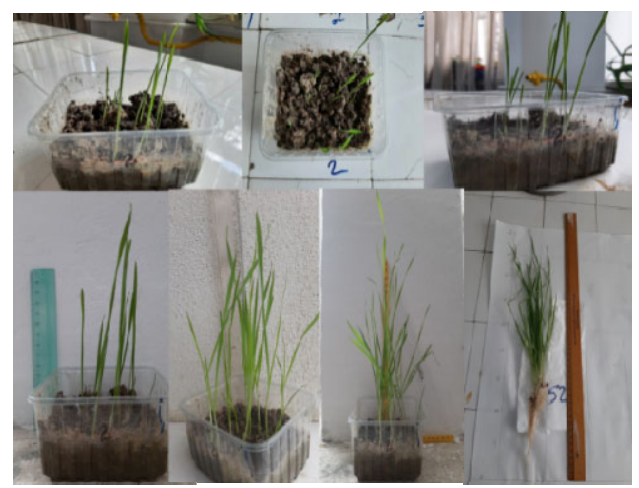

Figure 6- Plant development in S2 biosoil sample (soil/biomass with adsorbed textile dye)

\section{Root development}

The residual biomass presented in biosoils stimulated the growth of the roots, which is very important for obtaining the high-quality wheat crop.

The mass/weight of plant roots in biosoil samples referring to that in the control/reference soil ranged from a minimum of $0.00487 \mathrm{~g} / \mathrm{dry}$ plant $(0.99 \%)$ in S4 biosoil sample to a maximum of $0.01141 \mathrm{~g} /$ dry plant $(1.23 \%)$ in S1 biosoil sample (Table 6), which is not greatly significant. Biomass, by its content, provides a relatively complete intake of nutrients by the wheat plant. The presence of adsorbed $\mathrm{Cu}$ (II) species activates some herbal/ plant enzymes that are involved in the synthesis of lignin. Copper species, present in low content (S3 biosoil), did not potentiated the elongation of the root, but a slight branching appeared, related to other samples.

The reactive dye present in S2 biosoil sample negatively influences the development of the wheat plant root. The literature also indicates a negative influence of dyes on microbial soil communities (Imran et al., 2015). However, the presence of biomass in the S2 biosoil sample partially eliminated the inhibitory effect of the dye due to the fact that the mean mass of the aerial part of plants in S2 biosoil sample is higher than the control/reference soil (M) (Table 6, Fig. 7).

Table 6 - Plant mass increase in biosoils vs. reference soil

\begin{tabular}{lcccc}
\hline \multirow{2}{*}{ Biosoil sample } & \multicolumn{3}{c}{ Mean weight of plant (g) } & \multirow{2}{*}{ \% increase vs. control } \\
\cline { 2 - 4 } & root & aerian plant & total plant & \\
\hline M-control/ soil reference & 0.00875 & 0.01897 & 0.02772 & - \\
\hline S1(soil/ biomass) & 0.01141 & 0.02281 & 0.03422 & 1.23 \\
\hline S2 (soil/ biomass/dye) & 0.00716 & 0.02219 & 0.02935 & 1.05 \\
\hline S3 (soil/ biomass/Cu) & 0.00998 & 0.02372 & 0.03370 & 1.215 \\
\hline S4 (soil/ yeast) & 0.00487 & 0.02259 & 0.02746 & 0.99 \\
\hline
\end{tabular}


Usually, fertilization with yeast increases the activity of microorganisms in the soil, activates the processing of organic substances, which leads to the release of available phosphorus and nitrogen ionic forms, an effect that stimulates the development of plant roots. It is also a good source of phytohormones, cytokines and auxins. These substances favor the development of roots and upper parts of plants. For the biosoil sample with yeast (S4), in the case of the wheat crop, the lowest value of the mean root/upper plant mass was registered but the growth of the aerial part was stimulated.

For the control/reference soil, the minimum value of the mean mass ratio of the aerial part of the wheat plant was registered. This can be explained by the fact that the reserve of nutrients in the soil was consumed for the process of seeds germination and became insufficient for further development of plants. Better developed root system was observed in the wheat plants developed in $\mathrm{S} 1$ and $\mathrm{S} 3$ biosoil samples (Fig. 8).

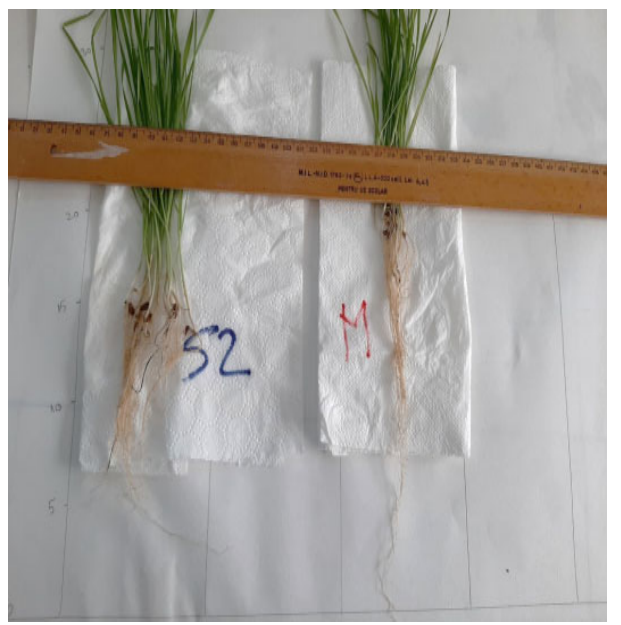

Figure 7- Inhibitory effect of the reactive dye on root development
Moreover, it was found that in the biosoil based on biomass (S1-S4), the length of the root exceeded the value found in the control/reference (M) soil sample by about $30 \%$. The most pronounced positive effects of residual biomass on plants were found at the level of the root system, demonstrated by increasing of $23 \%$ in the S1 biosoil sample with only residual biomass and of $21.5 \%$ in the S3 biosoil sample with residual biomass and adsorbed $\mathrm{Cu}$ species.

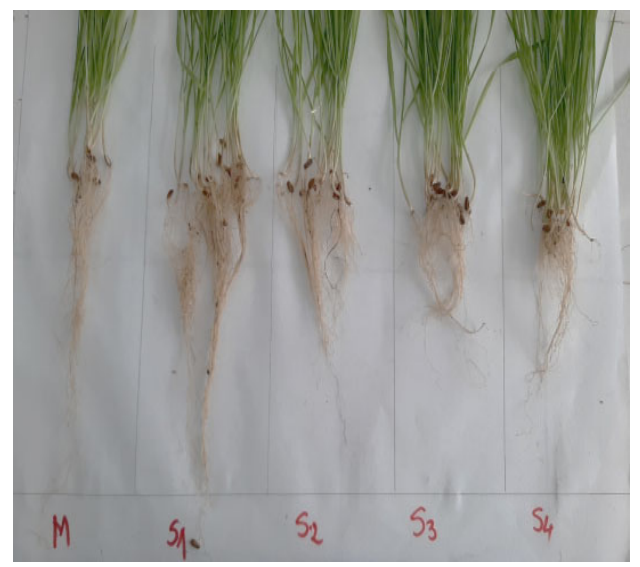

Figure 8 - Plant root system developed in all biosoils

\section{CONCLUSIONS}

The addition of residual biomass to the control/reference soil influences the development of plants in all experimental tests and permits the continuing study of these biosoils (at laboratory setup scale, but also in limited greenhouse exploratory areas) for possible applications in the ecological/ organic agriculture organized at large and intense practice scale. No significant essential changes were found in the values of biosoils $\mathrm{pH}$ (actual and potential exchangeable acidity) related 


\section{Ramona Elena TĂTARU-FARMUŞ ET AL.}

to the control/ reference soil, the development of the aerial part and roots of the wheat plants shows considerable differences.

The growth of the wheat plants in slightly alkaline biosoils proved that the supplementation with nutrients from residual biomass partially eliminated the symptoms of nutrients deficiency, manifested in the case of the control/reference soil sample by chlorosis and necrosis. In the S3 biosoil sample with copper microelement enrichment, the development of the aerial part of the wheat plants and the intense staining of the plants (possible due to the photosynthesis process intensification) was favored.

The cultivation of wheat plants on the proposed biosoils with various chemical composition has demonstrated the positive action on the physiological status of the wheat plants, through the healthier, more vigorous appearance of the plants, with a higher content of chlorophyll pigments (intense green plant color).

However, systematic investigations with other wheat varieties grown in the region, as well as with those grown in different regions, are needed at on-farm level.

Further, the results should be extrapolated at large agricultural area scale to check if they are corresponding to farmers' expectations and the residual biomass able to be used for cultivation of other types of crops, using other reference soil types from other geographic regions.

Acknowledgement. This research is supported by a grant of the Ministry of Research, Innovation and Digitization,
CNCS/CCCDI-UEFISCDI, project number 490PED/2020, within PNCDI II.

\section{REFERENCES}

Banerjee, M.R., Yesmin, L. \& Vessey, J.K. (2006). Plant growth-promoting rhizobacteria as biofertilizers and biopesticide. In: Handbook of microbial biofertilizers, Rai M.K. (Ed.),. Food Products Press, New York, 137-181.

Bashan, Y. \& De-Bashan, L.E. (2010). How the plant growth-promoting bacterium Azospirillum promotes plant growth - a critical assessment. Adv. Agron., 108: 77-136, DOI: 10.1016/S0065-2113(10) 08002-8

Calvo, P., Nelson, L. \& Kloepper, J.W. (2014). Agricultural uses of plant biostimulants. Plant Soil:, 383: 3-41, DOI: 10.1007/s11104-014-2131-8

Campobenedetto, C., Agliassa, C., Mannino, G., Vigliante, I., Contartese, V., Secchi, F. \& Bertea, C.M. (2021). A biostimulant based on seaweed (Ascophyllum nodosum and Laminaria digitata) and yeast extracts mitigates water stress effects on tomato (Solanum lycopersicum L.). Agriculture, 11: 557, DOI: 10.3390/agriculture1106 0557

Canbolat, M.Y., Barik, K., Çakmakçi, R. \& Șahin, F. (2006). Effects of mineral and biofertilizers on barley growth on compacted soil. Acta Agric. Scand., B Soil \& Plant Sci., 56(4): 324-332, DOI: 10.1080/09064710600591067

Cresser, M., Killham, K. \& Edwards, T. (1993). Soil chemistry and its applications, Cambridge University Press, (Cambridge Environmental Chemistry Series), 77-110, Cambridge, UK (ISBN 0521 32269)

Gallego, M.G., Skowyra, M., Gordon, M.H., Azman, N.A.M. \& Almajano, M.P. (2017). Effect of leaves of Caesalpinia decapetala on oxidative stability of oilin-water emulsions, Antioxidants (Basel), 6(1): 19, DOI: 10.3390/antiox 6010019

Gluck, A. (1971). Mathematical methods into the chemistry industry. Elements of 


\section{BIOMASS-BASED SOIL IN ECOLOGICAL AGRICULTURE}

optimization (in Romanian), Technical Publishing House, Bucharest, 124-148.

Grusak, M.A. (2001). Plant macro - and micronutrient minerals. In book: eLS, DOI:10.1038/npg.els.0001306

Hafez, M., Popov, A.I. \& Rashad, M. (2021). Integrated use of bio-organic fertilizers for enhancing soil fertility - plant nutrition, germination status and initial growth of corn (Zea mays L.), Environ. Technol. Innov., 21(1): 101329, DOI: 10.1016/j.eti.2020.101329

Imran, M., Crowley, D.E., Khalid, A., Hussain, S., Mumtaz, M.W. \& Arshad, M. (2015). Microbial biotechnology for decolorization of textile wastewaters. Rev. Environ. Sci. Biotechnol., 14(1): 73-92, DOI: 10.1007/s11157-014-93444

Jordan-Meille, L., Holland, J.E., McGrath, S.P., Glendining, M.J., Thomas, C.L. \& Haefele, S.M. (2021). The grain mineral composition of barley, oat and wheat on soils with $\mathrm{pH}$ and soil phosphorus gradients. Eur. J. Agron., 126, 126281, DOI: 10.1016/j.eja.2021. 126281

Kabata-Pendias, A. \& Pendias, H. (2001). Trace elements in soils and plants, 3rd ed., CRC Press, Boca Raton, FL.

LaMotte, Co. (2008). LaMotte Soil Handbook. La Motte Company Press, Chestertown, Maryland, U.S.A. www.lamotte.com

Lellis, B., Fávaro-Polonio, C.Z., Pamphile, J.A. \& Polonio, J.C. (2019). Effects of textile dyes on health and the environment and bioremediation potential of living organisms. Biotechnol. Res. Innov., 3(2): 275-290, DOI: 10.1016/j.biori.2019.09.001

Liteanu, C. (1969). Quantitative analytical chemistry. Volumetry (in Romanian), $5^{\text {th }}$ edition, Didactical and Educational Publishing House, Bucharest, 17-29.

Martins, L.L. \& Mourato, M.P. (2006). Effect of excess copper on tomato plants: Growth parameters, enzyme activities, chlorophyll and mineral content. J. Plant Nutr., 29: 2179-2198, DOI: 10.1080/01904160600972845

Masclaux-Daubresse, C., Daniel-Vedele, F., Dechorgnat, J., Chardon, F., Gaufichon, L. \& Suzuki, A. (2006). Nitrogen uptake, assimilation and remobilization in plants: challenges for sustainable and productive agriculture. Ann. Bot.,105(7): 1141-1157, DOI: 10.1093/aob/mcq028

Rehman, K., Shahzad, T., Sahar, A., Hussain, S., Mahmood, F. \& Siddique, M.H. (2018). Effect of Reactive Black 5 azo dye on soil processes related to $C$ and $\mathrm{N}$ cycling. Peer J., 6: e4802, DOI: 10.77 17/peerj.4802

Rengel, Z., Batten, G. \& Crowley, D. (1999). Agronomic approaches for improving the micronutrient density in edible portions of field crops. Field Crops Res., 60: 27-40, DOI: 10.1016/ S0378-4290(98)00131-2.

Standard SR ISO 8466-1 (1999). Calibration and assessment of the analysis methods and estimation of performance characteristics. Part 1, Romanian Institute of Standardization (IRS) Press, Bucharest, 1-8.

Stępień, A. \& Wojtkowiak, K. (2016). Effect of foliar application of $\mathrm{Cu}, \mathrm{Zn}$, and $\mathrm{Mn}$ on yield and quality indicators of winter wheat grain. Chilean J. Agric. Res., 76(2): 220-227, DOI: 10.4067/S071858392016000200012.

Surpăţeanu, M. \& Zaharia, C. (2005). Aspects concerning the soil degradation by acidification, Book of proceedings: Ecological Chemistry. Latest Advances, $3^{\text {rd }}$ Int. Conf. ECOCHEM2005, May 20-21, Chişinău, Republic of Moldova, 479-483, Publishing House of the Sciences Academy of Republic of Moldova, Chişinău (ISBN 9975-62-134-1).

Șuteu, D., Zaharia, C., Blaga, A.C. \& Peptu, A.C. (2021a). Biosorbents based on residual biomass of Lactobacillus $\mathrm{sp}$. bacteria consortium immobilized in sodium alginate for Orange 16 dye retention from aqueous solutions, Desalin. Water Treat., accepted manuscript ID TDWT-20212303.R1, in press.

Șuteu, D., Blaga, A.C., Zaharia, C. \& Horciu, I.L. (2021b). Residual biomass of Lactobacillus immobilized in alginate for Orange 16 dye retention from aqueous medium, Bulletin of Polytechnic Institute of lasi, series: 


\section{Ramona Elena TĂTARU-FARMUŞ ET AL.}

Chemistry and Chemical Engineering, 67(3): 63-72.

Tandzi, N.L. \& Mutengwa, S.Ch. (2020). Factors affecting yield of crops. In: Agronomy - Climate Change \& Food Security, Amanullah (Ed.), IntechOpen, DOI: 10.5772/intechopen.90672

Verhoog, H., Matze, M., Lammerts van Bueren, E. \& Baars, T. (2003). The role of the concept of the natural (naturalness) in organic farming. $J$. Agric. Environ. Ethics, 16: 29-49, DOI: 10.1023/A:1021714632012

Vita, F, Giuntoli, B. \& Arena, S. (2018). Effects of different nitrogen fertilizers on two wheat cultivars: An integrated approach. Plant Direct., 2(10): e00089, DOI: 10.1002/pld3.89
Yruela, I. (2009). Copper in plants: acquisition, transport and interactions. Funct. Plant Biol., 36(5): 409-430, DOI: 10.1071/FP08288.

Zaharia, C. (2014). Environmental chemistry - laboratory tests and problems (in Romanian). Performantica Publishing House, lasi, Romania.

Zahir, Z., Arshad, M. \& Frankenberger, M. (2003). Plant growth promoting rhizobacteria: applications and perspectives in agriculture. $A d v$. Agron., 81: 97-168, DOI: 10.1016/S00 65-2113(03)81003-9

***, (2008). Catalogue of standards, Technical Publishing House, Bucharest, Romania. 